This is the post_peer review, pre-publication version of the following article:

Osei, N.A., Gurnell, A.M., Harvey, G.L. 2015. The role of large wood in retaining fine sediment, organic matter and plant propagules in a small, single-thread forest river. Geomorphology 235: 77-87.

The published version is obatianable from http://dx.doi.org/10.1016/j.geomorph.2015.01.031

\title{
The role of large wood in retaining fine sediment, organic matter and plant propagules in a small, single-thread forest river
}

\author{
Nana A. Osei*, Angela M. Gurnell, Gemma L. Harvey \\ School of Geography, Queen Mary University of London, Mile End Road, London, E1 4NS, \\ $\mathrm{UK}$ \\ * Corresponding author. Tel.: +44 (0)7832915095; email address: n.osei@qmul.ac.uk.
}

\begin{abstract}
This paper investigates associations among large wood accumulations, retained sediment and organic matter, and the establishment of a viable propagule bank within a forested reach of a lowland river, the Highland Water, UK.

A wood survey within the $2 \mathrm{~km}$ study reach, illustrates that the quantity of wood retained within the channel is typical of relatively unmanaged river channels bordered by deciduous woodland, and that the wood accumulations (jams) that are present are well developed, typically spanning the river channel and comprised of wood that is well-decayed.

Sediment samples were obtained in a stratified random design focusing on 9 subreaches within which samples were aggregated from five different types of sampling location. Two of these locations were wood-associated (within and on bank faces immediately adjacent to wood jams) and the other three locations represented the broader river environment (gravel bars, bank faces, floodplain). The samples were analysed to establish their calibre, organic and viable plant propagule content.
\end{abstract}

The gravel bar sampling locations retained significantly coarser sediment containing a lower proportion of organic matter and viable propagules than the other four sampling locations. The two wood-related sampling locations retained sediment of intermediate calibre between the gravel bar and the bank - floodplain samples but they retained significantly more organic matter 
and viable propagules than were found in the other three sampling locations. In particular, the jam bank samples (areas of sediment accumulation against bank faces adjacent to wood jams) contained the highest number of propagules and the largest number of propagule species.

These results suggests that retention of propagules, organic matter and relatively fine sediment in and around wood jams has the potential to support vegetation regeneration, further sediment retention, and, as a consequence, landform development within woodland streams, although this process is arrested by grazing at the study site. These results also suggest that selfrestoration using wood is a potentially cost-effective and far-reaching river restoration strategy but that its full effects develop gradually and require the establishment of a functioning wood budget coupled with grazing levels that are in balance with vegetation growth.

Keywords: Large wood; Hydrochory; Sediment characteristics; River restoration

\section{Introduction}

Naturally-functioning forested rivers typically display complex riparian vegetation structure and fluvial forms that are driven by interactions among dead and living vegetation and fluvial processes (Gurnell, 2013). These interactions are reflected in the presence of a dynamic mosaic of large wood accumulations that induce spatial and temporal variations in flow velocity and patterns; erosion, sorting and deposition of sediments; the formation of landforms of varying sediment calibre including lateral bars and benches, eroded banks and side channels that strongly impact on the age structure and patchiness of the riparian forest (e.g. Gregory et al., 1991; Naiman et al., 2005; Latterell et al., 2006).

Large wood accumaltions in the active river channel not only significantly influence flow hydraulics, the retention and sorting of organic and inorganic fluvial sediments, and thus the morphological characteristics of the channel (e.g. Abbe and Montgomery, 2003), but these wood structures also perform important ecological functions as they are habitats in their own right; induce the development of other habitats, such as pools, vegetated and unvegetated bars, and side channels; provide shelter for organisms from predators as well as hydraulic refugia; and are a source of food. As a result, large wood structures support many organisms and their life history stages (e.g. Anderson et al., 1984; Benke and Wallace, 2003; Dolloff and Warren, 2003; Francis et al., 2008, Schneider and Winemiller, 2008). This paper contributes to research on associations among large wood, physical habitats and living organisms by exploring the 
relations between wood jams, sediment patches representative of particular physical habitats, and plant propagule retention.

Rivers are important for dispersing plant propagules across the landscape. The process of hydrochory (i.e. dispersal of diaspores by water, van der Pij1, 1982; Andersson et al., 2000) has been investigated by many researchers in relation to the colonisation of riparian zones and related influences on riparian vegetation communities (e.g. Nilsson et al., 1991; Nilsson and Grelsson, 1990; Andersson et al., 2000; Jansson et al., 2000; Gurnell et al., 2006). As well as floating freely in rivers, plant propagules can be transported within the water in the same manner as sediment particles, and by attaching to floating objects such as small pieces of wood, logs, twigs and leaves, and can then be stranded in large wood accumulations (Johansen and Hytteborn, 2001) and other obstructions within the channel. Indeed, deposition of relatively fine sediment in the shelter of obstacles on river bars and channel margins has been shown to be accompanied by the deposition of plentiful seeds and other plant propagules (Gurnell et al., 2007). Therefore, wood obstructions within river channels could be expected to provide important sediment and propagule retention sites. There is some published evidence for plant propagule retention by wood. Fetherston et al. (1995) and Abbe and Montgomery (2003) noted that trees colonise the bar surfaces that aggrade in the lee of bar-apex jams, and Collins et al. (2012) placed forest regeneration at the centre of their 'large wood cycle'. Furthermore, Pettit et al. (2006) surveyed some of the 200,000 wood piles deposited along a 105-km length of the Sabie River's bedrock macro-channel following a very large flood and found that vegetation regeneration from seedlings was occurring in $28 \%$ of wood piles and that wood was sprouting in $36 \%$ of the piles. The substantial vegetated patches that are produced by these processes not only influence further vegetation colonization and associated landform development but the resulting vegetated landforms can provide sufficient shelter from disturbance for areas of exposed sediment downstream, that seedlings can successfully initiate vegetation colonization of these sheltered areas (Moggridge and Gurnell, 2009). However, to our knowledge, no direct assessment of seed bank development associated with wood jams has been undertaken to date. This topic forms the focus of the present paper.

In parallel with the broader literature on the physical effects of large wood in rivers, three decades of research within the Highland Water, where the present research was conducted, has focused on the distribution and dynamics of large wood accumulations and their interactions with channel geomorphology (e.g. Gregory et al., 1985; Gregory and Davis, 1992; Gregory et al., 1994; Gurnell and Sweet, 1998). Research on the geomorphological role of large wood has 
concentrated on studying the varying physical properties of wood accumulations, the stability of pool-riffle sequences, and the number and size of pools associated with large wood accumulations (Piégay and Gurnell, 1997; Gurnell and Sweet, 1998; Gurnell et al., 2002; Millington and Sear, 2007). Research has also investigated how large wood accumulations influence floodplain sedimentation (Jeffries et al., 2003; Sear et al., 2010), focusing on the impact of wood retention on the frequency and duration of overbank and floodplain deposition, the formation of multi-channel patterns, and the formation and maintenance of floodplain surfaces. Biological research on the Highland Water has been limited. Recently, there has been some research on the significance of wood for fish populations (e.g. Langford et al., 2012). In addition, Sear et al. (2010) inferred that depositional features such as large wood accumulations along the Highland Water may be important germination sites for trees and shrubs. Nonetheless, there has been no formal research to investigate the possible relationships between large wood accumulations and plant propagule retention in the Highland Water.

This paper investigates associations between wood, sediment and plant propagule retention along a $2 \mathrm{~km}$ reach of the Highland Water. The study first explores the type and distribution of wood accumulations within the reach, and then considers the properties of sediment retained within five recurring types of sampling site within the river, two of which are wood-associated. The research addresses the following research questions:

i. What are the types and characteristics of large wood accumulations present within the studied river channel?

ii. What are the characteristics of sediments and associated plant propagules retained in the river channel in sampling locations within, near and between the wood accumulations?

iii. Are there any significant associations between sediment and plant propagule characteristics and the types of sampling location in which they are found?

\section{Study Area}

This study was conducted along a reach of the Highland Water, flowing through the New Forest, Hampshire, UK (Figure 1). The $2 \mathrm{~km}$ study reach has an average slope of $0.006 \mathrm{~m}_{\mathrm{m}} \mathrm{m}^{-1}$ and the relatively shallow active channel (approximately $1 \mathrm{~m}$ to bankfull level) extends to an average width of approximately $4 \mathrm{~m}$ (Gurnell and Sweet, 1998). The size of the bed material within the active channel is highly variable, ranging from local cobble-pebble deposits to more 
widespread coarse gravel deposits with frequent patches of sand and silt. The banks are composed mainly of sand, silt and clay sized particles with gravel lenses.

The study reach is bordered by old, mainly deciduous woodland, including alder (Alnus glutinosa (L.) Gaertn), ash (Fraxinus excelsior L.), birch (Betula pubescens Ehrh.), beech (Fagus sylvatica L.), holly (Ilex aquifolium L.), oak (Quercus petraea (Mattuschaka.) Leibel.) and several species of willow (Salix spp.). The woodland is largely unmanaged, although grazing of the ground vegetation and lower branches by ponies, deer and cattle is intense. The river channel is also essentially unmanaged and follows a sinuous course through the woodland with large wood and other tree-related features such as exposed tree roots forming important structures and geomorphic features within the channel bed and banks. Despite the heavy grazing, the lack of management of large wood and riparian woodland, make the Highland Water one of a very small number of sites in England suitable for this study, since the majority of English rivers have been subject to riparian tree management and wood removal over many decades even centuries. This paper focuses on sediment retained by wood accumulations (hereafter called jams) and associated geomorphic units and considers the calibre and organic content of the sediment and its associated seed bank.

\section{Methods}

\subsection{Field methods}

The approximately $2 \mathrm{~km}$ long study reach was divided into nine contiguous $200 \mathrm{~m}$ sub-reaches (Figure 1). Two types of data or samples were collected from all nine sub-reaches: (i) all large wood jams were located and their characteristics were recorded; (ii) sediment samples were collected to provide data on sediment calibre, organic content and the plant propagule bank.

\subsubsection{Large wood jam survey}

Although many definitions of 'large wood' have been used (Hassan et al., 2005), large wood was defined for the present study as wood pieces exceeding $1 \mathrm{~m}$ in length and $0.1 \mathrm{~m}$ in diameter. All large wood jams that spanned at least $20 \%$ of the channel width were surveyed between 9 and 12 May 2011 to record the properties listed in Table 1.

Each jam was characterised according to its position, type (following the classification of Gregory et al., 1995), and decay status (Table 1). Position was categorised with respect to the 
the nearest river bend; type was categorised on the basis of the way the jam interacted with flow; and a simple three-fold categorisation of decay status reflected the predominant level of decay of the large wood pieces as an indicator of jam age and stability. The outer dimensions (length, width and height) of the jam were also measured as was the channel width at the location of the jam.

For each jam, the number and dimensions (length and diameter) of all large wood pieces were measured, from which the length and diameter of the largest (key) piece, the ratio of the key piece length to the channel width, and the average length and width of the key pieces were estimated. All measurements were made to the nearest $5 \mathrm{~cm}$ for lengths and $1 \mathrm{~cm}$ for diameters using a $30 \mathrm{~m}$ measuring tape and a $1 \mathrm{~m}$ rigid rule.

The volumes of wood pieces (estimated from length and diameter) and jams (estimated from length, width and depth) were also calculated, with a correction to the latter of 0.2 to estimate the wood volume rather than wood-air volume (Gurnell et al., 2000).

\subsubsection{Sediment sampling}

Samples of mineral and organic sediment and their contained propagule bank were collected during May 2011 using a stratified random sampling design. The sampling period followed the recession of the major winter and spring floods and preceded the main summer flowering period for the majority of species and so essentially captured the persistent seed bank (Hodgson et al., 1995; Thompson et al., 1997).

Samples were collected from within each of the nine sub-reaches. In each sub-reach, sediment samples were collected from five types of location: bare (unvegetated) side- and mid-channel gravel bar surfaces (BGB); within wood jams (JM); the lower face / toe of banks immediately adjacent (upstream or downstream) to wood jams (JB); the face of bare eroding banks located away from wood jams (BK); and the top of the bank / floodplain edge surface (FP) (Figure 2). These locations were chosen because they represented ubiquitous locations within and around wood jams and across the broader river bed, banks and floodplain, including two wood-related locations (JM and JB) and three commonly-occurring locations that were not directly related to wood jams (BGB, BK, FP).

Three (for JM, JB, BK, FP) and four (for BGB) widely-spaced, replicate samples of each location type were obtained from each sub-reach and these were combined to provide a single, aggregate sample of each type. The larger number of samples for BGB locations were to ensure 
that sufficient finer sediment was obtained for laboratory analysis from these coarse sediments. Each sample was obtained using a cylindrical corer ( $5 \mathrm{~cm}$ deep, $6 \mathrm{~cm}$ diameter), and so we extracted samples to a depth of $5 \mathrm{~cm}$, which is typical for seed bank studies (Thompson et al., 1997). The sub-reaches were sampled in sequence from downstream to upstream to avoid sample contamination from transported sediment.

In relation to the propagule bank, the aim of the study was not to undertake a detailed ecological analysis of its composition and abundance, which would have required many more samples and sampling occasions as well as a different and more lengthy treatment of the samples. Rather, the aim was to evaluate the degree to which viable propagules are characteristic of sediments drawn from particular geomorphological locations and show differences among these locations.

\subsection{Laboratory methods}

Following preparation and storage, two groups of methods were adopted in the laboratory: (i) analysis of particle size and organic content; (ii) assessment of the viable propagule bank through germination trials.

\subsubsection{Sediment preparation and storage}

Each sediment sample (aggregate of three replicate samples) was weighed, thoroughly mixed and concentrated by sieving through a $4 \mathrm{~mm}$ sieve (Goodson et al., 2001). The $<4 \mathrm{~mm}$ fraction includes the entire propagule bank (Thompson et al., 1997) and so concentrates the propagules within the sample extracted for germination trials. The volume and weight of the $>4 \mathrm{~mm}$ and $<4 \mathrm{~mm}$ fractions were measured for inclusion in the particle size analysis of the sediments. Two sub-samples of the $<4 \mathrm{~mm}$ fraction were extracted for (i) particle size and organic content analysis and (ii) germination trials. The samples for propagule bank analysis were placed in cold storage (below $0^{\circ} \mathrm{C}$ ) and all samples were subjected to germination trials at the same time. This ensured equal treatment of the samples with the aim of achieving comparability in the germination trial results rather than maximising the number of propagules and species germinated.

\subsubsection{Particle size and organic content analysis}


$100 \mathrm{ml} \mathrm{sub}$-samples were extracted from each $(<4 \mathrm{~mm})$ sample reserved for particle size and organic content analysis. Each was weighed into a crucible, dried in an oven for 48 hours at $55^{\circ} \mathrm{C}$, desiccated in a vacuum desiccation chamber and re-weighed, combusted in a furnace for $5 \mathrm{hrs}$. at $550^{\circ} \mathrm{C}$, desiccated once again in a vacuum desiccation chamber after the combustion process and reweighed to determine percentage loss-on-ignition of organic matter (Bott, 2006). The combusted organic matter was expressed as a percentage of the dry sample weight.

The remaining mineral sediment sample was sieved through $2 \mathrm{~mm}$ and $1 \mathrm{~mm}$ meshes and a $5 \mathrm{~g}$ sub-sample of the $<1 \mathrm{~mm}$ fraction was analysed using a Beckman laser sizer to obtain a particle size distribution for the $<1 \mathrm{~mm}$ fraction. The resultant data were combined with information on the coarser fractions to provide estimates of the percentages of the dry weight of the original aggregate field sample that were gravel, sand, silt and clay.

\subsubsection{Germination trials}

$250 \mathrm{ml}$ sub-samples were extracted from each $(<4 \mathrm{~mm})$ sample reserved for germination trials. Germination trials were undertaken for 12 weeks, since it can take time for some species to germinate (Baskin and Baskin, 2003; Finch-Savage and Leubner-Metzger, 2006). The $250 \mathrm{ml}$ sub-samples were spread on top of $500 \mathrm{ml}$ sterilised compost (FertileFibre ${ }^{\circledR}$ ) in bottomdraining $20.5 \times 15 \times 5 \mathrm{~cm}$ plastic seed trays and $50 \mathrm{ml}$ of vermiculite was sprinkled on top to help prevent desiccation. Seed trays were arranged randomly in the germination room, watered daily and then illuminated using 600-W Growmaster model Metal-Halide lamps for a period of $16 \mathrm{~h}$ per day (Gurnell et al., 2008). Seed trays were periodically rotated in position to avoid differences in light exposure and the soil surface was periodically disturbed to break up any surface barriers created by mould or algae (Amrein et al., 2005; Adams and Steigerwalt, 2011). The seedling emergence method was used to determine the number of viable propagules in the sediment sample (Thompson et al., 1997; see Boedeltje et al., 2002 for aquatic plants). As propagules germinated they were identified to species level and then removed from the seed tray. Where seedlings proved difficult to identify, they were transplanted into pots and grownon until it was possible to identify their species or in some cases their genus.

In addition to the number of taxa recorded in each sample (propagule species richness), the number of viable propagules per unit volume (propagules per litre) and surface area (propagules per square metre) of the original bulk sample were estimated to allow comparison with other published data (e.g. Butler and Chazdon, 1998; Gurnell et al., 2007, 2008). 
The above, standardised approach to seed germination aimed to provide comparable (relative) germination trial results based on a manageable laboratory effort. However, it is important to note that more complex and time-consuming treatments are needed if the germination requirements of all species are to be met and a more comprehensive evaluation of the viable propagule bank is to be achieved (e.g. Boedjelte et al., 2002, 2003).

The variables derived from the analysis of particle size and organic content and the assessment of the viable propagule bank are listed in Table 2.

\subsection{Data analysis}

Data derived from the raw field and laboratory measurements were assessed using descriptive statistics to explore whether any trends were apparent in the data. Most of the monitored variables were not normally distributed and the variables frequently showed differences in variance between sampling location types, so non-parametric statistical methods were used for data analysis. Kruskal-Wallis (KW) tests were used to explore the differences in the variables among the sampling location types. Where KW tests indicated a significant difference $(p<0.05)$ in a particular variable, multiple pairwise comparisons were then performed using Dunn's procedure (Bonferroni corrected significance level) to identify which sampling location types showed significant differences in the variable. Multivariate associations within the data set were then explored using two ordination techniques: Principal Components Analysis (PCA) to investigate the particle size and organic content properties of the samples and Detrended Correspondence Analysis (DCA) to explore the species composition of the samples. KW tests and PCA were performed using XLSTAT-Pro software (version 9.1.3, 2009), while DCA was performed using CANOCO v4.5 (ter Braak and Smilauer, 2002).

\section{Results}

\subsection{Characteristics of wood jams}

A total of 141 large wood pieces were incorporated into 25 major wood jams within the 9 studied sub-reaches of the Highland Water (Figure 1). The majority of jams were located at river bends (13 jams, $52 \%$ ), were complete jams (11, $44 \%$ ), and were comprised of large wood pieces with partially decayed xylem (15, $60 \%)$. Four (16\%), $11(44 \%), 7(28 \%)$, and 3 (12 $\%)$ jams were, respectively, active, complete, partial or high types, illustrating that the majority 
of the jams were in contact with the bed and crossed the entire channel (i.e. $15(60 \%)$ were active or complete jams). Only five jams (20\%) showed complete bark removal, and the same number showed only partial bark removal, illustrating that most of the jams $(15,60 \%)$ were composed of wood that was predominantly in an advanced stage of decay.

Jams and their constituent large wood pieces varied greatly in size along the study reach (Figure 3). The median jam length, width and depth were $3.15 \mathrm{~m}, 2.5 \mathrm{~m}$ and $0.79 \mathrm{~m}$, respectively, but the volume of jams varied widely, ranging from $0.4 \mathrm{~m}^{3}$ to $408.0 \mathrm{~m}^{3}$ (median $6.12 \mathrm{~m}^{3}$ ). The wood volume of the jams within the study reach was estimated to be $56.7 \mathrm{~m}^{3} / \mathrm{ha}$. Each jam contained an average of six large wood pieces (median, 4). The median wood piece length and diameter were $2.50 \mathrm{~m}$ and $0.14 \mathrm{~m}$, respectively, but wood piece sizes were highly variable with wood piece volumes ranging from $0.004 \mathrm{~m}^{3}$ to $10.804 \mathrm{~m}^{3}$ (median $0.041 \mathrm{~m}^{3}$ ). Key wood pieces had a median length of $4.0 \mathrm{~m}$ and median diameter of $0.22 \mathrm{~m}$. The median length of the key wood piece within the 25 jams relative to the local channel width was 1.38 .

\subsection{Sediment calibre and organic content}

Despite the small sample size and variability in each of the sediment characteristics from each type of sampling location, box and whisker plots show apparent differences in most of the sediment characteristics according to sampling location type (Figure 4). Kruskal Wallis tests ( $p<0.0001$ in all cases) followed by multiple pairwise comparisons revealed statistically significant differences $(\mathrm{p}<0.05)$ between bare gravel bar $(B G B)$ samples and those from the other four location types in each of the sediment properties (Table 3). Jam bank samples (JB) showed significantly higher percentage organic matter (\%OM) than gravel bar samples (BGB). Floodplain (FP) samples showed a significantly higher percentage sand $(\% \mathrm{~S})$ and lower percentage gravel $(\% \mathrm{G})$ than gravel bar samples (BGB), whereas bank (BK) and floodplain (FP) samples were found to be significantly finer $\left(\mathrm{D}_{50}\right)$ and showed significantly higher silt $(\% \mathrm{ST})$ and clay $(\% \mathrm{C})$ content than jam (JM) and gravel bar (BGB) samples.

To explore multivariate contrasts in sediment properties among the samples, Principal Components Analysis (PCA) was used to identify gradients in the sediment characteristics across the 45 samples ( 9 for each sampling location type). Because the variables were percentages and were not normally distributed, PCA was performed on a rank correlation matrix. In this analysis $\% \mathrm{ST}$ and $\% \mathrm{C}$ were combined because they were very highly correlated $(\mathrm{r}=0.99, \mathrm{p}<0.0001)$ and so they each provided almost identical information. The first principal 
component (PC1, Table 4) explained over $74 \%$ of the variance in the data set and described a gradient of decreasing particle size with $\% \mathrm{G}$ showing a strong positive loading and $\mathrm{D}_{50}$ (phi), $\% \mathrm{~S}$ and $\% \mathrm{ST}+\% \mathrm{C}$ showing strong negative loadings. The second principal component (PC2, Table 4) explained $18 \%$ of the variance in the data set and had one very strong positive loading on \%OM. Therefore PC2 described a gradient of increasing percent organic matter in the samples.

Figure 5 plots the scores of the 45 samples on PC1 and PC2, and codes them according to sampling location type, using circles for jam-associated locations (JM, JB) and triangles for other locations (FP, BK, BGB). A Kruskal Wallis test comparing scores on PC1 according to sampling location type was highly significant $(\mathrm{p}<0.0001)$. Multiple pairwise comparisons revealed that BGB samples had significantly higher scores (i.e. were coarser) than FP, JB and BK samples, and JM samples had significantly higher scores than FP samples $(p<0.05)$. A Kruskal Wallis test applied to sample scores on PC2 was also highly significant $(p<0.0001)$, with JB and JM samples having significantly higher scores (i.e. higher organic content) than BK and BGB samples $(\mathrm{p}<0.05)$. Thus, BGB, JM, JB, BK and FP samples are well discriminated according to their scores on PC1 and PC2.

\subsection{Propagule bank}

In total 19,609 propagules of 25 species and 3 genus ( 2 woody, 3 rush, 19 herb, 4 grass, Table 5) germinated from the sediment samples across the five sampling location types. Propagule species richness and abundance varied in the sediment samples collected across the five sampling location types (Figure 6). Kruskal Wallis tests followed by multiple pairwise comparisons revealed that propagule species richness was significantly higher $(p<0.05)$ in the samples from jam banks (JB) and banks (BK) than in gravel bar samples (BGB), whereas propagule abundance was significantly higher $(\mathrm{p}<0.05)$ in jam bank $(\mathrm{JB})$ and floodplain $(\mathrm{FP})$ samples than in bare gravel bars (BGB) (Table 3).

To explore more subtle gradients in the species composition of the propagule bank among the samples from the different sampling location types, an indirect gradient analysis, Detrended Correspondence Analysis (DCA), was applied to the species presence data. All species and genus were included in the analysis and there was no downweighting of rare species. Eigenvalues for the first two axes were 0.363 and 0.298 and the lengths of gradient were 2.997 and 2.675. These two axes only explain a total of $23.4 \%$ of the variance in the species data. 
Figure 7 shows the DCA biplot for the propagule species (Figure 7A) and the samples coded by sampling location type (Figure 7B). Although there are some detailed differences in the distribution of the samples from different sampling locations with respect to the species, there are no clear and consistent differences to suggest that propagule species composition varies with sampling location (Figure 7B). This probably reflects the fact that sampling was only undertaken at a single time when propagule species diversity was likely to be low, and the sampling effort, storage and germination trials were not designed to maximise the number of species and propagles that germinated but to support a preliminary assessment of relative differences among five geomorphologically different sampling locations. Therefore, although the number of species and the abundance of propagules varies significantly among the sampling locations, with the jam bank samples showing the highest combination of species richness and propagule abundance (Table 3, Figure 6), there are no particularly distinctive contrasts in the overall species composition of sets of samples drawn from the five different sampling location types particularly from the JM, JB, BK and FP locations (Figure 7).

\section{Discussion and Conclusions}

\subsection{Large wood jams}

An enormous body of research has emerged over the last three decades, demonstrating the importance of wood to river ecosystems (Gregory et al., 2003). In this context, an important property of large wood is its size in relation to the size of the river channel (Gurnell, 2013), since this affects the formation of channel-spanning jams that can have an enormous impact on flow hydraulics, sediment retention and transfer, and physical habitat construction. In spite of the rather small wood piece dimensions identified along the Highland Water, the key wood piece length to bankfull width ratio within the 25 studied wood jams was an important factor influencing jam size, the size of other wood pieces recruited into jams, and the stability of the wood and the jams as suggested by other studies (e.g. Braudrick and Grant, 2000, 2001; Martin and Benda, 2001; Abbe and Montgomery, 2003).

The majority of jams were wedged at river bends (52\%) and completely spanned the river channel and its bed (44\%). Judging from their decay status (the majority of wood pieces showing partially decayed xylem in $60 \%$ of the jams), the jams represent long-term wood retention within the river and probably long term persistence of individual jams. Indeed, the persistence of jams within the Highland Water has been demonstrated previously by Gurnell 
and Sweet (1998), who showed that although the type of jam may change through time the location of the largest jams changes little.

Furthermore, the estimated volume of wood in the studied reach $\left(56.7 \mathrm{~m}^{3} / \mathrm{ha}\right)$ is typical for relatively unmanaged rivers bordered by deciduous woodland (Gurnell, 2013). Thus, the studied reach provides an example of typical levels of wood accumulation within a river bordered by deciduous woodland, where wood has been accumulating in the longer term to form substantial, persistent jams.

As illustrated by Baillie et al. (2008), larger, longer and more stable than average large wood pieces within jams influence channel morphology and habitat development. For example, wood pieces and jams along the Highland Water have previously been shown to strongly influence the abundance and distribution of different types of pool (Gurnell and Sweet, 1998). The structure and persistence of wood features coupled with their impact on channel morphology creates a complex environment within which sediment retention is likely to be high. Understanding the character of the sediment that is retained in association with some of these complex features contributes to a better understanding of the contribution of wood to river ecosystems.

\subsection{Sediment}

Considerable spatial heterogeneity was observed in the sediment calibre and organic matter content of samples obtained from different sampling locations in the studied reach. However, there was significant sediment fining $\left(D_{50}\right)$ from bars to jams and jam banks through to floodplain and bank sampling locations, placing the two wood-related sampling locations (jams and jam banks) in an intermediate position between the gravel bed and floodplain sediments in terms of their sediment calibre. Bank and floodplain samples were significantly finer, with bank samples containing a higher proportion of silt and clay, while floodplain samples contained significantly more sand. The latter may accord with the observation of sand splays on the floodplain following overbank flows typical of spring floods by Sear et al. (2010). The two wood-related sampling locations also retained significantly more organic matter than bars and banks. Thus wood provides sites for retention of sizeable quantities of relatively fine, organic-rich sediment that would otherwise have few retention sites within the active river channel. 


\subsection{Plant propagules}

Seeds and vegetative fragments of plants form part of the river's load of organic material, and hydrochory (dispersal of propagules by water) has been shown to be a key process for dispersing propagules downstream along rivers from the catchment species pool (e.g. Andersson and Nilsson, 2002; Goodson et al., 2003; Boedeltje et al., 2004) and laterally into the riparian corridor (Johansson et al., 1996; Goodson et al., 2003; Gurnell et al., 2008). The abundance of viable propagules found in samples from the study reach (up to 9138 propagules per square metre) is somewhat higher than those reported for other wooded riparian areas (e.g. Ferris and Simmons, 2000; Goodson et al., 2001), despite the fact that the laboratory methods were not designed to maximise propagule abundance but rather to identify relative contrasts in abundance among five different types of sampling location.

The jam bank samples retained the highest numbers of viable propagules as well as the highest number of propagule species, although there were no specific species associated with the jam bank or any of the other types of samples. Propagule retention is important for the establishment of vegetation in riparian and aquatic habitats, and it appears that the sampled wood-associated habitats are hotspots for such retention. As noted in the introduction, Abbe and Montgomery (2003) and Fetherston et al. (1995) describe the development of woody vegetation on wood accumulations along the Queet's River, USA, and Collins et al. (2012) refer to a large wood cycle, where wood jams that are incorporated into the floodplain provide hardspots on which the oldest trees are able to develop. The research presented here, illustrates that propagule retention by wood is a significant process in the study reach, which has the potential to feed a cycle of vegetation development, further sediment retention, and consequently in-channel vegetated landform development associated with the wood jams. Furthermore, high propagule retention is associated with the retention of relatively fine organic sediment which is suitable to support germination and early growth of the seedlings. Unfortunately, heavy grazing in the New Forest may prevent this potential being achieved. The relatively low species richness (28 taxa) of viable propagules found during this study may also reflect restriction of the species pool due to heavy grazing within the riparian forest bordering the river. The pressure of grazing, reduces the number of seedlings that reach maturity, and hence retards regeneration of the ground vegetation (Douglas and Pouliet, 1997; Clary, 1999; Shaw and Kernot, 2004). However, the time of sampling (May) as well as the sampling and laboratory methods employed, which were not designed to achieve a full ecological analysis but to investigate relative differences among the five types of sampling 
location, are very likely to have reduced the propagule species richness observed.

Furthermore, most of the seedlings identified in the present study were from species with a persistent seed bank (that is seeds remain viable for $>1$ year; Thompson and Grime, 1979; Thompson et al., 1997), reflecting the fact that many plant species set seeds in summer and also produce seeds with a shorter period of viability than one year. Strong seasonal variations observed in the composition of bank top, bank face and channel bed seed banks and their species traits along two other UK rivers, support these suppositions (Gurnell et al., 2007, 2008). This research on two reaches of the River Frome (southern England) and one reach of the River Tern (central England), revealed the highest species richness in propagule banks deposited and accumulated between October and January (i.e. following the summer) and highest abundance in propagule banks deposited and accumulated between June and September. Species traits (plant functional types, longevity of viability, dispersule weight) varied between the background (mainly persistent) propagule bank (sampled during May as in the present study) and depositional additions to the propagule bank accumulated over four sampling periods (June to September, October to January, February to May, June to October). The research also demonstrated how inundation depth, duration and frequency; and the hydraulic conditions affecting the sampling locations, inferred from the calibre of sediment deposited; were important explanatory variables for propagule abundance and species richness. These observations and those made in flume experiments by Merritt and Wohl (2002) also support the implications of the present research that there is strong interaction between fluvial processes including hydrochory and the characteristics of sampling locations. Overall, competition, herbivory, propagule functional traits, and the frequency and magnitude (depth and duration) of flood inundation may account for the supply of propagules to different sampling locations by hydrochory, but the overall flow resistance and complexity of the wood jams explains why the wood-associated sampling locations provide important retention sites for propagules and other organic matter. The longer-term geomorphological and plant ecological role of wood jams and jam banks may be simply be as temporary storage sites for propagules that are remobilised and transferred elsewhere by floods. However, in the absence of grazing these substantial wood-related features are most likely to act as germination sites, on which plants grow, sediment accumulates and the sites eventually evolve into landforms such as vegetated bars, benches, islands and extensions of the flooplain as indicated by Abbe and Montgomery (2003) and Gurnell et al. (2005). 


\subsection{Importance of large wood jams for river restoration}

Recently, restoration schemes have started to incorporate the reintroduction of large wood to enhance channel structural and hydraulic complexity and thus to re-establish the physical and ecological functions associated with large wood jams in undisturbed river systems (Palmer et al., 2010). The value of large wood for improving hydraulic diversity, driving widespread sediment sorting and redistribution, and as a resource for river restoration and recovery has been demonstrated by research relating habitat complexity to fish and macroinvertebrate community indices (e.g. Crispin et al., 1993; Sotir, 1998; MacNally et al., 2001; Lester and Boulton, 2008; Nagayama et al., 2008). The study reported here has shown that well established wood jams not only influence channel morphology and sediment structure but they also have an important role in plant propagule, organic matter and fine sediment retention. This effect is almost certainly enhanced by the age, complexity and state of decomposition of the wood in the studied jams, and so the effect of wood on these retention processes builds over many decades as a dynamic wood budget establishes, rather than being an instant gain from wood emplacement.

The availability of plant propagules is an important factor for landform development and the regeneration and restoration of natural habitats as the propagule bank functions as a latent plant community (Thompson, 1992; Bakker et al., 1996). Propagules concentrate in areas of flow separation or low shear stress, characteristic of wood jams, following depositional processes (Abernethy and Wilby, 1999; Goodson et al., 2001; Andersson and Nilsson, 2002; Tabacchi et al., 2005), and these environments can provide suitable environmental conditions (nutrients, moisture, disturbance etc.) for germination. Propagules of many plant species have been shown to have the ability to tolerate and germinate or sprout in relatively disturbed river habitats (Barrat-Segretain et al., 1999; Barrat-Segretain and Bornette, 2000). Consequently, the progressive deposition and accretion of sediment and propagules, sprouting of earlysuccessional germinants and the eventual colonization success of vegetation in the woodrelated patches sampled in the Highland Water may be important factors for determining earlier successional processes and plant diversity (Barrat-Segretain et al., 1998; Pollock et al., 1998; Middleton, 1999; Guilloy-Froget et al., 2002) and may also influence channel and floodplain development (Fetherston et al., 1995; Montgomery and Abbe, 2006; Collins et al., 2012). Linking with observations in less heavily-grazed rivers (e.g. Abbe and Montgomery, 2003; Collins et al., 2012), the wood-related propagule and sediment retention process has the 
potential to feed cycles of vegetation regeneration, sediment retention and landform development that are at present arrested by grazing within the New Forest.

Overall, wood appears to play an important role in the physical and biological development of rivers and has the potential to drive river self-restoration. Emplacement of wood in rivers has important physical effects, but time is needed for the wood budget to develop and for welldeveloped accumulations to appear. Such accumulations undoubtedly have important geomorphological impacts on the surrounding channel. However, the results presented here suggest that plant propagule banks within large wood-related patches may be important tools in the conservation of plant species and in contributing to the trajectory of floodplain morphological and forest development. However, further research involving a larger number of samples, repeated (i.e. seasonal) sampling, and a different methodology for sample storage and processing samples is required if the full plant ecological implications of the retained propagule banks are to be appreciated. Finally, this process of river self-restoration driven by wood is very cost-effective but it needs to be recognised that it requires not only the establishment of a functioning wood budget but also the maintenance of grazing at levels where vegetation and herbivores are in balance.

\section{Acknowledgement}

This research is supported by a Queen Mary University of London studentship awarded to N.A. Osei and many additional resources provided by the School of Geography. We thank the Forestry Commission for permission to collect sediment samples along the Highland Water, and Dr. Christopher Cockel for his advice and help on seedling identification. We also thank three anonymous reviewers for their helpful and constructive comments which have helped to improve the quality of this manuscript.

\section{References}

Abbe, T.B., Montgomery, D.R., 2003. Patterns and processes of wood debris accumulation in the Queets river basin, Washington. Geomorphology 51, 81-107.

Abernethy, V.J., Willby, N.J., 1999. Changes along a disturbance gradient in the density and composition of propagule banks in floodplain aquatic habitats. Plant Ecology 140 (2), 177-190. 
Adams, C.R., Steigerwalt, N.M., 2011. Methodology for wetland seedbank assays. Environmental Horticulture, Florida Cooperative Extension Service, Institute of Food and Agricultural Sciences, University of Florida, Gainsville, FL. EDIS, ENH1090, 2008.

Amrein, D., Rusterholz, H.P., Baur, B., 2005. Disturbance of suburban Fagus forests by recreational activities: Effects on soil characteristics, above-ground vegetation and seed bank. Applied Vegetation Science 8, 175-182.

Anderson, N.H., Steedman, R.J., Dudley, T., 1984. Patterns of exploitation by stream invertebrates of woody debris (xylophagy). Internationale Vereinigung für Theoretische und Angewandte Limnologie 22, 1847-1852.

Andersson, E., Nilsson, C., Johansson, M.E., 2000. Plant dispersal in boreal rivers and its relation to the diversity of riparian flora. Journal of Biogeography 27, 1095-1106.

Andersson, E., Nilsson, C., 2002. Temporal variation in the drift of plant litter and propagules in a small boreal river. Freshwater Biology 47, 1674-1684.

Baillie, B.R., Garrett, L.G., Evanson, A.W., 2008. Spatial distribution and influence of large woody debris in an old-growth forest river system, New Zealand. Forest Ecology and Management 256, 20-27.

Bakker, J.P., Poschlod, P., Strykstra, R.J., Bekker, R.M., Thompson, K., 1996. Seedbanks and seed dispersal: important topics in restoration ecology. Acta Botanica Neerlandica 45 (4), 461 490.

Barrat-Segretain, M.H., Bornette, G., Hering-Vilas-Bas, A., 1998. Comparative abilities of vegetative regeneration among aquatic plants growing in disturbed habitats. Aquatic Botany $60,201-211$.

Barrat-Segretain, M.H., Henry, C.P., Bornette, G., 1999. Regeneration and colonisation of aquatic plants fragments in relation to the disturbance frequency of their habitat. Archiv für Hydrobiologie 145, 111-127.

Barrat-Segretain, M.H., Bornette, G., 2000. Regeneration and colonisation abilities of aquatic plant fragments: effect of disturbance seasonality. Hydrobiologia 421, 31-39.

Baskin, C.C., Baskin, J.M., 2003. When breaking seed dormancy is a problem: Try a movealong experiment. Native Plants Journal 4 (1), 17-21. 
Benke, A.C., Wallce, J.B., 2003. Influence of wood on invertebrate communities in stream and rivers. In: Gregory, S., Boyer, K., Gurnell, A.M. (Eds.), The Ecology and Management of Wood in World Rivers. American Fisheries Society, Symposium 37, Bethesda, Maryland, pp. 149-177.

Boedeltje, G., ter Heerdt, G.N.J., Bakker J.P., 2002. Applying the seedling-emergence method under waterlogged conditions to detect the seed bank of aquatic plants in submerged sediments. Aquatic Botany 72, 121-128.

Boedeltje, G., Bakker, J.P., Bekker, R.M., Van Groenendael, J.M., Soesbergen, M., 2003. Plant dispersal in a lowland stream in relation to occurrence and three specific life-history traits of the species in the species pool. Journal of Ecology 91, 855-866.

Boedeltje, G., Bakker, J.P., Ten Brinke, A., van Groenendael, J.M., Soesbergen, M., 2004. Dispersal phenology of hydrochorous plants in relation to discharge, seed release time and buoyancy of seeds: the flood pulse concept supported. Journal of Ecology 92, 786-796.

Bott, T.L., 2006. Primary productivity and community respiration. In: Hauer, F.R., Lamberti, G.A. (Eds.), Methods in Stream Ecology, 2nd edition. Elsevier, New York, pp. 263-290.

Braudrick, C.A., Grant, G.E., 2000. When do logs move in rivers? Water Resources Research $36,571-583$.

Braudrick, C.A., Grant, G.E., 2001. Transport and deposition of large wood debris in streams: A flume experiment. Geomorphology 41, 263-283.

Butler, B.J., Chazdon, R., 1998. Species richness, spatial variation and abundance of the soil seed bank of a secondary tropical rain forest. Biotropica 30, 214-222.

Capon, S.J., 2003. Plant community responses to wetting and drying in a large arid floodplain. River Research and Applications 19, 509-520.

Clary, W.P., 1999. Riparian-stream habitat responses to late spring cattle grazing. In: Eldridge D., Freudenberger, D. (Eds.), People and Rangelands: Building the Future, Proceedings of the VI International Rangeland Congress. Townsville, Queensland, Australia, vol 1 \& 2, pp. 695697.

Cockel, C.P., Gurnell, A.M., 2012. An investigation of the composition of the urban riparian soil propagule bank along the River Brent, Greater London, UK, in comparison with previous propagule bank studies in rural areas. Urban Ecosystems 15 (2), 367-387. 
Collins, B.D., Montgomery, D.R., Fetherston, K.L., Abbe, T.B., 2012. The floodplain largewood cycle hypothesis: A mechanism for the physical and biotic structuring of temperate forested alluvial valleys in the North Pacific coastal ecoregion. Geomorphology 139-140, 460470.

Combroux, I., Bornette, G., 2004. Effects of two types of disturbance on seed-bank and their relationship with established vegetation. Journal of Vegetation Science 15, 13-20.

Cranston, P.S., McKie, B., 2006. Aquatic wood-an insect perspective. In: Grove, S.J., Hanula, J.L. (Eds.), Insect biodiversity and dead wood: proceedings of a symposium for the 22nd International Congress of Entomology. Gen. Tech. Rep. SRS-93. Asheville, NC: U.S. Department of Agriculture Forest Service, Southern Research Station. 109 pp.

Crispin, V., House, R., Roberts, D., 1993. Changes in instream habitat, large woody debris, and salmon habitat after the restructuring of a coastal Oregon stream. North American Journal of Fisheries Management 13, 96-102.

del Tánago, M.G., de Jalón, D.G., 2006. Attributes for assessing the environmental quality of riparian zones. Limnetica 25 (1-2), 389-402.

Dolloff, C.A., Warren, M.L., 2003. Fish relationships with large wood in small streams. In: Gregory, S., Boyer, K., Gurnell, A.M. (Eds.), The Ecology and Management of Wood in World Rivers. American Fisheries Society, Symposium 37, Bethesda, Maryland, pp. 179-193.

Douglas, M., Pouliet, A., 1997. A review of the impacts of the northern Australian grazing industry on wetlands and riparian habitats. In: Hook, R. (Ed.), The Northern Australian Program: Catchment Management, Water Quality and Nutrient Flows in Northern Australia and the Northern Australian Beef Industry, NAP Occasional Publication, no. 3, Meat and Livestock Australia, pp. R2-1 - R2-20.

Ferris, R., Simmons, E., 2000. Plant Communities and Soil Seedbanks in Broadleaved-Conifer Mixtures on Ancient Woodland Sites in Lowland Britain. Forestry Commission, Edinburgh, 8 pp.

Fetherston K.L., Naiman R.J., Bilby R.E., 1995. Large woody debris, physical processes, and riparian forest development in montane river networks of the Pacific Northwest. Geomorphology 13, 133-144.

Finch-Savage, W.E., Leubner-Metzger, G., 2006. Seed dormancy and the control of germination. New Phytologist 171, 501-523. 
Francis, R.A., Tibaldeschi, P., McDougall L., 2008. Fluvially-deposited large wood and riparian plant diversity. Wetlands Ecology and Management 16 (5), 371-382.

Galatowitsch, S.M., van der Valk, A.G., 1996. The vegetation of restored and natural prairie wetlands. Ecological Applications 6, 102-112.

Goodson, J.M., Gurnell, A.M., Angold, P.G., Morrissey, I.P., 2001. Riparian seed banks: structure, process and implications for riparian management. Progress in Physical Geography $25,301-325$.

Goodson, J.M., Gurnell, A.M., Angold, P.G., Morrissey, I.P., 2003. Evidence for hydrochory and the deposition of viable seeds within winter flow-deposited sediments: The River Dove, Derbyshire, UK. River Research and Applications 19, 317-334.

Gregory, K.J., Davis, R.J., 1992. Coarse woody debris in stream channels in relation to river channel management in woodland areas. Regulated Rivers: Research and Management 7, $117-$ 136.

Gregory, K.J., Gurnell, A.M., Hill, C.T., 1985. The permanence of debris dams related to river channel processes. Hydrological Sciences Journal 30, 371-381.

Gregory, S.V., Swanson, F.J., McKee, W.A., Cummins, K.W., 1991. An ecosystem perspective of riparian zones. Bioscience 41, 540-551.

Gregory, K.J., Gurnell, A.M., Hill, C.T., Tooth, S., 1994. Stability of the pool-riffle sequence in changing river channels. Regulated Rivers: Research and Management 9 (1), 35-43.

Gregory, K.J., Gurnell, A.M., Petts, G.E., 1995. The role of dead wood in aquatic ecosystems in forests. In: Brown, I.R. (Ed.), Forests and Water. Institute of Chartered Foresters, Edinburgh, pp. 158-192.

Gregory, S.V., Meleason, M.A., Sobota, D.J., 2003. Modeling the dynamics of wood in streams and rivers. In: Gregory, S., Boyer, K., Gurnell, A.M. (Eds.), The Ecology and Management of Wood in World Rivers. American Fisheries Society, Symposium 37, Bethesda, Maryland, pp. 315-335.

Guilloy-Froget, H., Muller, E., Barsoum, N., Hughes, F.M.R., 2002. Dispersal, germination and survival of Populus nigra L. (Saliacaceae) in changing hydrologic conditions. Wetlands $22,478-488$. 
Gurnell, A.M., 2013. Wood in fluvial systems. In: Shroder, J., Wohl, E. (Eds.), Treatise on Geomorphology, vol. 9, Fluvial Geomorphology. Academic Press, San Diego, pp. 163-188.

Gurnell, A.M., Gregory, K.J., 1987. Vegetation characteristics and the prediction of runoff: Analysis of an experiment in the New Forest, Hampshire. Hydrological Processes 1 (2), 125142.

Gurnell, A.M., Gregory, K.J., 1995. Interactions between seminatural vegetation and hydrogeomorphological processes. Geomorphology 13 (1-4), 49-69.

Gurnell, A.M., Sweet, R., 1998. The distribution of large woody debris accumulations and pools in relation to woodland stream management in a small, low-gradient stream. Earth Surface Processes and Landforms 23 (12), 1101-1121.

Gurnell, A.M., Gregory, K.J., Petts, G.E., 1995. The role of a coarse woody debris in forest aquatic habitats: Implications for management. Aquatic Conservation: Marine and Freshwater Ecosystems 5, 143-166.

Gurnell, A.M., Petts, G.E. Hannah, D.M., Smith, B.P.G., Edwards, P.J., Kollmann, J., Ward, J.V., Tockner, K., 2000. Wood storage within the active zone of a large European gravel-bed river. Geomorphology 34, 55-72.

Gurnell, A.M., Piégay, H., Swanson, F.J., Gregory, S.V., 2002. Large wood and fluvial processes. Freshwater Biology 47, 601-619.

Gurnell A.M., Angold, P.G., Goodson, J.M., Morrissey, I.P., Petts, G.E., Steiger, J., 2004. Vegetation propagule dynamics and fluvial geomorphology. In: Bennett, S.J., Simon, A. (Eds.), Riparian Vegetation and Fluvial Geomorphology. American Geophysical Union, Water Science and Applications Series 8, Washington, pp. 209-219.

Gurnell, A.M., Boitsidis, A.J., Thompson, K., Clifford, N.J., 2006. Seed bank, seed dispersal and vegetation cover: colonization along a newly created river channel. Journal of Vegetation Science 17, 665-674.

Gurnell, A., Goodson, J., Thompson, K., Clifford, N., Armitage, P., 2007. The river-bed: a dynamic store for plant propagules? Earth Surface Processes and Landforms 32, 1257-1272.

Gurnell, A.M., Thompson, K., Goodson, J., Moggridge, H., 2008. Propagule deposition along river margins: linking hydrology and ecology. Journal of Ecology 96, 553-565. 
Harwell, M.C., Havens, K.E., 2003. Experimental studies on the recovery potential of submerged aquatic vegetation after flooding and desiccation in a large subtropical lake. Aquatic Botany 77, 135-151.

Hassan, M.A., Hogan, D.L., Bird, S.A., May, C.L., Gomi, T., Campbell, D., 2005. Spatial and temporal dynamics of wood in headwater streams of the Pacific Northwest. Journal of the American Water Resources Association 41, 899-919.

Hodgson, J.G., Grime, J.P., Hunt, P., Thompson, K., 1995. The Electronic Comparative Plant Ecology. Chapman and Hall, London, 24pp.

Jansson, R., Nilsson, C., Dynesius, M., Andersson, E., 2000. Effects of river regulation on river-margin vegetation: a comparison of eight boreal rivers. Ecological Applications 10, 203224.

Jeffries, R.J., Darby, S.E., Sear, D.A., 2003. The influence of vegetation and organic debris on floodplain sediment dynamics: a case study of a low-energy stream in the New Forest, Hampshire. Geomorphology 51, 61-80.

Johansen, S., Hytteborn, H., 2001. A contribution to the discussion of biota dispersal with drift ice and driftwood in the North Atlantic. Journal of Biogeography 28, 105-115.

Johansson, M.E., Nilsson, C., Nilsson, E., 1996. Do rivers function as corridors for plant dispersal? Journal of Vegetation Science 7, 593-598.

Keller, E.A., Swanson, F.J., 1979. Effects of large organic material on channel form and fluvial processes. Earth Surface Processes and Landforms 4, 361-380.

Kochel, R.C., Ritter, D.F., Miller, J., 1987. Role of tree dams in the construction of pseudoterraces and variable geomorphic response to floods in Little River valley, Virginia. Geology $15,718-721$.

Langford, T.E.L., Langford, J., Hawkins, S.J., 2012. Conflicting effects of woody debris on stream fish populations: implications for management. Freshwater Biology 57 (5), 1096-1111. Latterell, J.J., Bechtold, J.S., O'Keefe, T.C., Van Pelt, R., Naiman, R.J., 2006. Dynamic patch mosaics and channel movement in an unconfined river valley of the Olympic Mountains. Freshwater Biology 51, 523-544.

Leck, M.A., 1989. Wetland seed banks. In: Leck, M.A., Parker, V.T., Simpson, R.L. (Eds.), Ecology of Soil Seed Banks. Academic Press, London, pp. 283-303. 
Leck, M.A., Brock, M.A., 2000. Ecological and evolutionary trends in wetlands: Evidence from seeds and seed banks in New South Wales, Australia and New Jersey, USA. Plant Species Biology 15, 97-112.

Lester, R. E., Boulton, A.J., 2008. Rehabilitating agricultural streams in Australia with wood: a review. Environmental Management 4, 310-326.

MacNally, R., Parkinson, A., Horrocks, G., Conole, L., Tzaros, C., 2001. Relationships between terrestrial vertebrate diversity, abundance and availability of coarse woody debris on south-eastern Australian floodplains. Biological Conservation 99, 191-205.

Martin, D.J., Benda, L.E., 2001. Patterns of instream wood recruitment and transport at the watershed scale. Transactions of the American Fisheries Society 130, 940-958.

Merritt, D.M., Wohl, E.E., 2002. Processes governing hydrochory along rivers: Hydraulics, hydrology, and dispersal phenology. Ecological Applications 12(4), 1071-1087.

Middleton, B., 1999. Wetland Restoration, Flood Pulsing and Disturbance Dynamics. John Wiley and Sons, New York, 400pp.

Millington, C.E., Sear, D.A., 2007. Impacts of river restoration on small-wood dynamics in a low-gradient headwater stream. Earth Surface Processes and Landforms 32 (8), 1204-1218.

Moggridge, H.L., Gurnell, A.M., 2009. Controls on the sexual and asexual regeneration of Salicaceae along a highly dynamic, braided river system. Aquatic Sciences 71, 305-317.

Montgomery, D.R., Abbe, T.B., 2006. Influence of logjam-formed hard points on the formation of valley-bottom landforms in an old-growth forest valley, Queets River, Washington, USA. Quaternary Research 65, 147-155.

Nagayama, S., Kawaguchi, Y., Nakano, D., Nakamura, F., 2008. Methods for and fish responses to channel remeandering and large wood structure placement in the Shibetsu River Restoration Project in northern Japan. Landscape and Ecological Engineering 4, 69-74.

Naiman, R.J., Décamps, H., McClain, M.E., 2005. Riparia: Ecology, Conservation and Management of Streamside Communities. Elsevier Academic Press, London, 448pp.

Narver, D.W., 1971. Effects of Logging Debris on Fish Populations. In: Morris, J. (Ed.), Proceedings of a Symposium-Forest land uses and stream environment. Oregon State University, Corvallis, Oregon (USA), pp. 100-111. 
Nilsson, C., Grelsson, G., 1990. The effects of litter displacement on riverbank vegetation. Canadian Journal of Botany 68, 735-741.

Nilsson, C., Gardfjell, M., Grelsson, G., 1991. Importance of hydrochory in structuring plant communities along rivers. Canadian Journal of Botany 69 (12), 2631-2633.

Palmer, M.A., Holly, L.M., Bernhardt, E., 2010. River restoration, habitat heterogeneity and biodiversity: a failure of theory or practice? Freshwater Biology 55 (1), 205-222.

Pettit, N.E., Latterell, J.J., Naiman, R.J., 2006. Formation, distribution and ecological consequences of flood-related wood debris piles in a bedrock confined river in semi-arid South Africa. River Research and Applications 22 (10), 1097-1110.

Piégay, H., Gurnell, A.M., 1997. Large woody debris and river geomorphological pattern: Examples from S.E France and S. England. Geomorphology 19 (1-2), 99-116.

Pollock, M.M., Naiman, R.J., Hanley, T.A., 1998. Plant species richness in riparian wetlandsa test of biodiversity theory. Ecology 79 (1), 94-105.

Schneider, K.N., Winemiller, K.O., 2008. Structural complexity of woody debris patches influences fish and macroinvertebrate species richness in a temperate floodplain-river system. Hydrobiologia 610, 235-244.

Sear, D.A., Millington, C.E., Kitts, D.R., Jeffries, R., 2010. Logjam controls on channel:floodplain interactions in wooded catchments and their role in the formation of multichannel patterns. Geomorphology 116 (3-4), 305-319.

Sedell, J.R., Richey, J.E., Swanson F.J., 1989. The river continuum concept: A basis for the expected ecosystem behavior of very large rivers? In: Dodge, D.P. (Ed.), Proceedings of the International Large River Symposium. Canadian Special Publication of Fisheries and Aquatic Sciences, vol. 106. Canadian Government Publishing Centre, Ottawa, pp. 49-55.

Shaw, K.A., Kernot, J.C., 2004. Extent of dense native woodland and exotic weed infestation in the extensive grazing lands of the Upper Herbert and Upper Burdekin River Catchments of far north Queensland: results of a producer survey. Tropical Grasslands 38, 112-116.

Shearer, C.A., 1972. Fungi of the Chesapeake Bay and its tributaries. III. The distribution of wood-inhabiting Ascomycete and Fungi Imperfecti of the Patuxent River. American Journal of Botany 59 (9), 961-969. 
Sotir, R.B., 1998. Criteria for Woody Vegetation Placement in Streambank Protection. In: Hayes, D.F. (Ed.), Engineering Approaches to Ecosystem Restoration. Proceedings of the 1998 Wetlands Engineering and River Restoration Conference. American Society of Civil Engineers, Denver, Colorado, pp. 259-265.

Tabacchi, E., Planty-Tabacchi, A.M., Nadal, E., Roques, L., 2005. Seed inputs along riparian zones: implications for plant invasion. River Research and Applications 21, 299-313.

ter Braak, C.J.F., Šmilauer, P., 2002. CANOCO Reference Manual and CanoDraw for Windows User`s Guide. Software for Canonical Community Ordination (version 4.5). Biometris, Wageningen and České Budějovice. 500pp.

Thompson, K., 1992. The functional ecology of seed banks. In: Fenner, M. (Ed.), Seeds: The Ecology of Regeneration in Plant Communities. C.A.B International, Wallingford, pp. 231258.

Thompson, K., Grime, J.P., 1979. Seasonal variation in the seed banks of herbaceous species in ten contrasting habitats. Journal of Ecology 67, 893-921.

Thompson, K., Bakker, J.P., Bekker, R.M., 1997. The Soil Seed Banks of North West Europe: Methodology, Density and Longevity. Cambridge University Press, Cambridge, 288pp.

Tockner, K., Pennetzdorfer, D., Reiner N., Schiemer, F., Ward, J.V., 1999. Hydrological connectivity, and the exchange of organic matter and nutrients in a dynamic river-floodplain system (Danube, Austria). Freshwater Biology 41, 521-535.

van der Pijl, L., 1982. Principles of Dispersal in Higher Plants, 3rd edition. Springer, Berlin, 232pp. 
Table 1. Characteristics recorded for all wood jams.

\begin{tabular}{|c|c|}
\hline Variable & Description \\
\hline $\begin{array}{l}\text { Jam position } \\
\text { (upstream, downstream, at } \\
\text { bend) }\end{array}$ & $\begin{array}{l}\text { Upstream: jam located upstream of a bend. } \\
\text { Downstream: jam located downstream of a bend. } \\
\text { At bend: jam located at the crest of a bend. }\end{array}$ \\
\hline $\begin{array}{l}\text { Jam type } \\
\text { (active, complete, partial, } \\
\text { high) }\end{array}$ & $\begin{array}{l}\text { Active: jam completely spans the channel width and is } \\
\text { sufficiently impermeable that it induces a step in the } \\
\text { water surface slope under baseflow conditions. } \\
\text { Complete: jam completely spans the channel width and is } \\
\text { sufficiently permeable that no step in the water surface } \\
\text { slope is induced under baseflow conditions. } \\
\text { Partial: jam only spans part of the channel width. } \\
\text { High: key piece(s) is / are suspended above the channel } \\
\text { bed and thus only influence flow hydraulics during high } \\
\text { flows. }\end{array}$ \\
\hline $\begin{array}{l}\text { Jam decay status } \\
\text { (partly decayed, bark } \\
\text { removed, bark partly } \\
\text { removed showing xylem) }\end{array}$ & $\begin{array}{l}\text { Partly decayed: jams showing predominantly large wood } \\
\text { with partly decayed xylem. } \\
\text { Bark removed: jams showing predominantly large wood } \\
\text { with bark (almost) completely removed. } \\
\text { Bark partly removed: jams showing predominantly large } \\
\text { wood with bark only partly removed or intact. }\end{array}$ \\
\hline $\begin{array}{l}\text { Number of large wood } \\
\text { pieces in jam }\end{array}$ & Total number of large wood pieces in the jam. \\
\hline Key wood piece length & Length of the largest wood piece in the jam (m). \\
\hline Key wood piece diameter & $\begin{array}{l}\text { Mid-stem diameter mid-stem of the largest wood piece in } \\
\text { the jam }(\mathrm{m}) \text {. }\end{array}$ \\
\hline $\begin{array}{l}\text { Ratio of key wood piece } \\
\text { length to channel width }\end{array}$ & $\begin{array}{l}\text { Length of the longest (key) wood piece relative to the } \\
\text { channel width. }\end{array}$ \\
\hline Wood piece length & Average length of large wood pieces within the jam (m). \\
\hline Wood piece diameter & $\begin{array}{l}\text { Average mid-stem diameter of large wood pieces within } \\
\text { the jam }(\mathrm{m}) \text {. }\end{array}$ \\
\hline Jam length & $\begin{array}{l}\text { Distance from the upstream to downstream edges of the } \\
\text { wood jam measured parallel to the river channel axis }(\mathrm{m}) \text {. }\end{array}$ \\
\hline Jam width & $\begin{array}{l}\text { Width of the jam measured perpendicular to the river } \\
\text { channel axis }(\mathrm{m}) \text {. }\end{array}$ \\
\hline Jam depth & $\begin{array}{l}\text { Maximum depth of the wood jam measured vertically } \\
\text { from the river bed }(\mathrm{m}) \text {. }\end{array}$ \\
\hline Jam volume & $\begin{array}{l}\text { The volume of the smallest rectangular box (including } \\
\text { air) into which a wood jam would fit }\left(\mathrm{m}^{3}\right) \text {. Following } \\
\text { Gurnell et al. ( } 2000) \text {, the wood +air volumes were } \\
\text { adjusted to produce estimates of wood volume by } \\
\text { multiplying the jam volume by } 0.2 \text {. }\end{array}$ \\
\hline
\end{tabular}


Table 2. Properties recorded for bulked (aggregated) sediment samples extracted from five sampling location types along the study reach of the Highland Water.

\begin{tabular}{|c|c|c|}
\hline Variable & Abbreviation & Description \\
\hline$\%$ Organic matter & $\% \mathrm{OM}$ & $\begin{array}{l}\text { Percentage organic matter content of bulk sample } \\
\text { dry weight. }\end{array}$ \\
\hline $\begin{array}{l}\text { Median particle size } \\
\text { (phi units) }\end{array}$ & $\mathrm{D}_{50}$ & Median particle size of bulk sample dry weight. \\
\hline$\%$ Gravel & $\% \mathrm{G}$ & Percentage gravel of bulk sample dry weight. \\
\hline$\%$ Sand & $\% \mathrm{~S}$ & Percentage sand of bulk sample dry weight. \\
\hline$\%$ Silt & $\% \mathrm{ST}$ & Percentage silt of bulk sample dry weight.. \\
\hline$\%$ Clay & $\% \mathrm{C}$ & Percentage clay of bulk sample dry weight. \\
\hline Species richness & TPropSR & The total number of propagule species identified. \\
\hline Propagules per litre & TProp/1 & $\begin{array}{l}\text { The number of viable propagules per unit volume } \\
\text { sampled in the field. }\end{array}$ \\
\hline $\begin{array}{l}\text { Propagules per } \\
\text { square metre }\end{array}$ & TProp $/ \mathrm{m}^{2}$ & $\begin{array}{l}\text { The number of viable propagules per unit surface } \\
\text { area sampled in the field. }\end{array}$ \\
\hline
\end{tabular}

Table 3. Statistically significant differences $(\mathrm{p}<0.05)$ in sediment and propagule bank variables of samples obtained from five sampling location types, identified using Kruskal-Wallis tests with multiple pairwise comparisons performed using Dunn's procedure with Bonferroni correction.

\begin{tabular}{lc}
\hline Variables & Significant differences among sampling location types \\
\hline Sediment & \\
$\% \mathrm{OM}$ & $\mathrm{JB}>\mathrm{BGB}$ \\
$\mathrm{D}_{50}$ & $\mathrm{BK}, \mathrm{FP}>\mathrm{JM}, \mathrm{BGB}$ \\
$\% \mathrm{G}$ & $\mathrm{BGB}>\mathrm{FP}$ \\
$\% \mathrm{~S}$ & $\mathrm{FP}>\mathrm{BGB}$ \\
$\% \mathrm{ST}$ & $\mathrm{BK}>\mathrm{BGB}$ \\
$\% \mathrm{C}$ & $\mathrm{BK}, \mathrm{FP}>\mathrm{BGB}$ \\
Propagule bank & \\
TPropSR & $\mathrm{JB}, \mathrm{BK}>\mathrm{BGB}$ \\
TProp $/ 1$ & $\mathrm{FP}, \mathrm{JB}>\mathrm{BGB}$ \\
TProp $/ \mathrm{m} 2$ & $\mathrm{JB}, \mathrm{FP}>\mathrm{BGB}$ \\
\hline
\end{tabular}


Table 4. Eigenvalues, percent variance explained and sediment characteristic loadings on the first two principal components (PC1, PC2) of a Principal Components Analysis (PCA) performed on the sediment characteristics of all bulk sediment samples from five location types.

\begin{tabular}{lcc}
\hline & $\mathrm{PC} 1$ & $\mathrm{PC} 2$ \\
\hline Eigenvalue & 3.720 & 0.902 \\
Variance explained (\%) & 74.407 & 18.044 \\
Cumulative variance (\%) & 74.407 & 92.451 \\
& & \\
Loadings & & \\
$\% \mathrm{OM}$ & -0.377 & 0.925 \\
$\mathrm{D}_{50}$ & -0.955 & -0.183 \\
$\% \mathrm{G}$ & 0.977 & 0.052 \\
$\% \mathrm{~S}$ & -0.908 & -0.031 \\
$\% \mathrm{ST}+\% \mathrm{C}$ & -0.942 & 0.100 \\
\hline
\end{tabular}


Table 5. Plant species/genus germinated from samples drawn from different sampling location types.

\begin{tabular}{|c|c|c|c|c|c|c|}
\hline \multirow[b]{2}{*}{ Species name } & \multicolumn{6}{|c|}{ Sampling Location } \\
\hline & Abbreviation & BGB & $\mathrm{BK}$ & $\mathrm{JM}$ & JB & $\mathrm{FP}$ \\
\hline Agrostis sp. & Agr sp & & $\mathrm{X}$ & & $\mathrm{X}$ & $\mathrm{X}$ \\
\hline Ajuga reptans & Aju rep & $\mathrm{X}$ & & & & $X$ \\
\hline Alisma plantago-aquatica & Ali p-a & & $X$ & $X$ & $X$ & $\mathrm{X}$ \\
\hline Alnus glutinosa & Aln glu & $\mathrm{X}$ & $X$ & $X$ & $X$ & \\
\hline Apium nodiflorum & Api nod & & & $\mathrm{X}$ & & \\
\hline Betula pubescens & Bet pub & & $X$ & $X$ & $X$ & $X$ \\
\hline Callitriche hamulata & Cal ham & & & & $\mathrm{X}$ & \\
\hline Callitriche stagnalis & Cal sta & & $\mathrm{X}$ & & $\mathrm{X}$ & $\mathrm{X}$ \\
\hline Cardamine pratensis & Car pra & & $X$ & & & \\
\hline Carex pendula & Car pen & $\mathrm{X}$ & $X$ & $\mathrm{X}$ & $\mathrm{X}$ & $\mathrm{X}$ \\
\hline Carex sp. & Car sp & $\mathrm{X}$ & $\mathrm{X}$ & $\mathrm{X}$ & $\mathrm{X}$ & $\mathrm{X}$ \\
\hline Digitalis purpurea & Dig pur & & $X$ & & & $X$ \\
\hline Epilobium ciliatum & Epi cil & $\mathrm{X}$ & & & & $\mathrm{X}$ \\
\hline Epilobium hirsutum & Epi his & $X$ & $\mathrm{X}$ & $X$ & $\mathrm{X}$ & \\
\hline Euphorbia sp. & Eup sp & & & & & $\mathrm{X}$ \\
\hline Festuca gigantea & Fes gig & & $\mathrm{X}$ & & & $\mathrm{X}$ \\
\hline Hypericum humifusum & Hyp hum & & & & $\mathrm{X}$ & $\mathrm{X}$ \\
\hline Juncus acutiflorus & Jun acu & $X$ & $X$ & $X$ & $X$ & $X$ \\
\hline Juncus effusus & Jun eff & $X$ & $X$ & $\mathrm{X}$ & $X$ & $\mathrm{X}$ \\
\hline Luzula campestris & Luz cam & & & $\mathrm{X}$ & & \\
\hline Persicaria hydropiper & Per hyd & $\mathrm{X}$ & & & $\mathrm{X}$ & \\
\hline Prunella vulgaris & Pru vul & & $X$ & $\mathrm{X}$ & & $\mathrm{X}$ \\
\hline Ranunculus repens & Ran rep & & $X$ & & & \\
\hline Sagina procumbens & Sag pro & $X$ & $X$ & $X$ & $X$ & $X$ \\
\hline Senecio vulgaris & Sen vul & & $X$ & $X$ & $X$ & $X$ \\
\hline Sonchus oleraceus & Son ole & & & & & $X$ \\
\hline Stachys sylvatica & Sta syl & & & & $\mathrm{X}$ & \\
\hline Taraxacum officinale agg. & Tar agg & & & & $\mathrm{X}$ & \\
\hline Veronica serpyllifolia & Ver ser & & $\mathrm{X}$ & & & \\
\hline
\end{tabular}



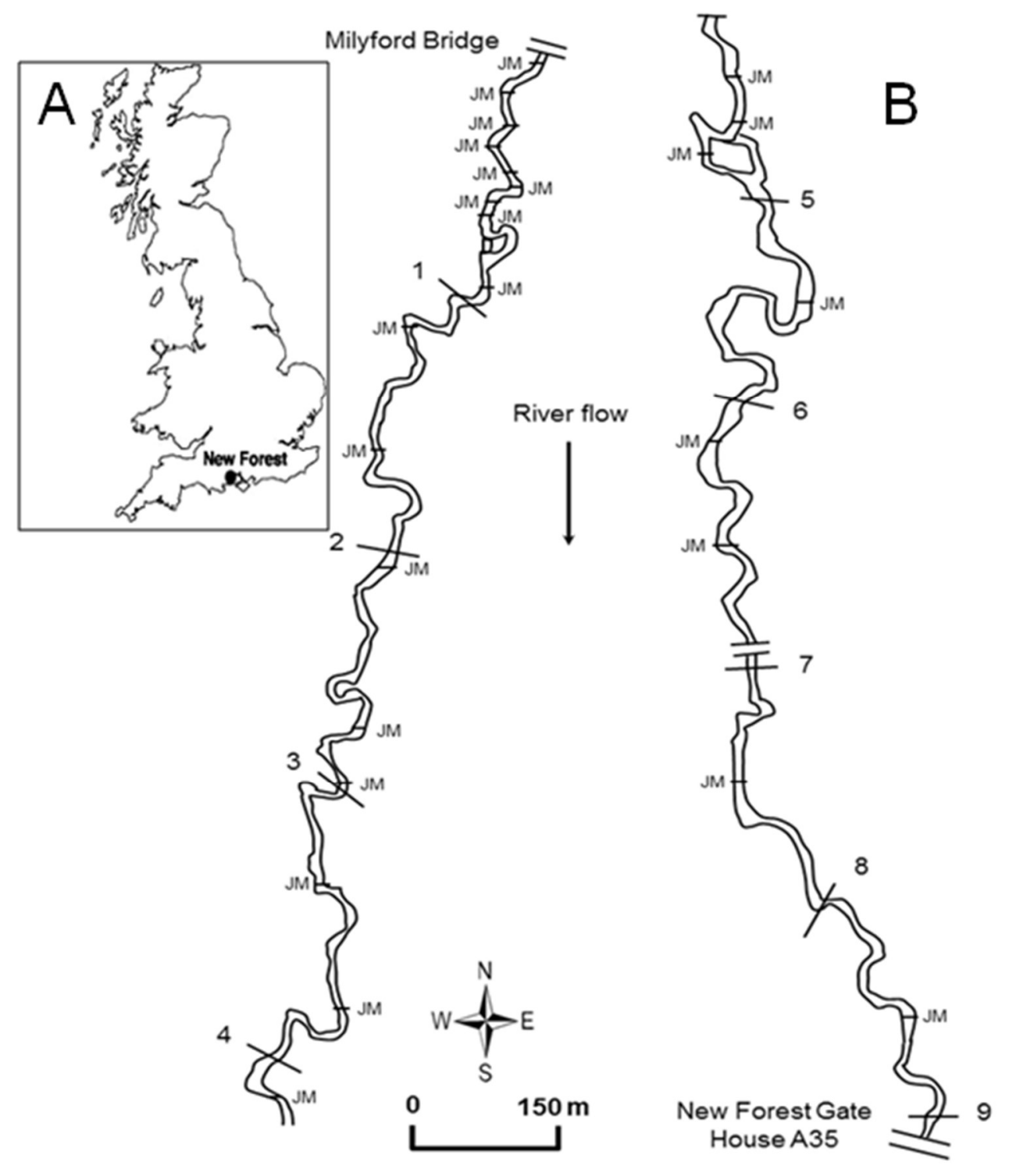

Fig. 1. (A) Location of Highland Water in the New Forest, South England; (B) the Highland Water study reach, showing the location of the sampling sub-reaches and the investigated jams (JM) from upstream (top left) to downstream (bottom right). 


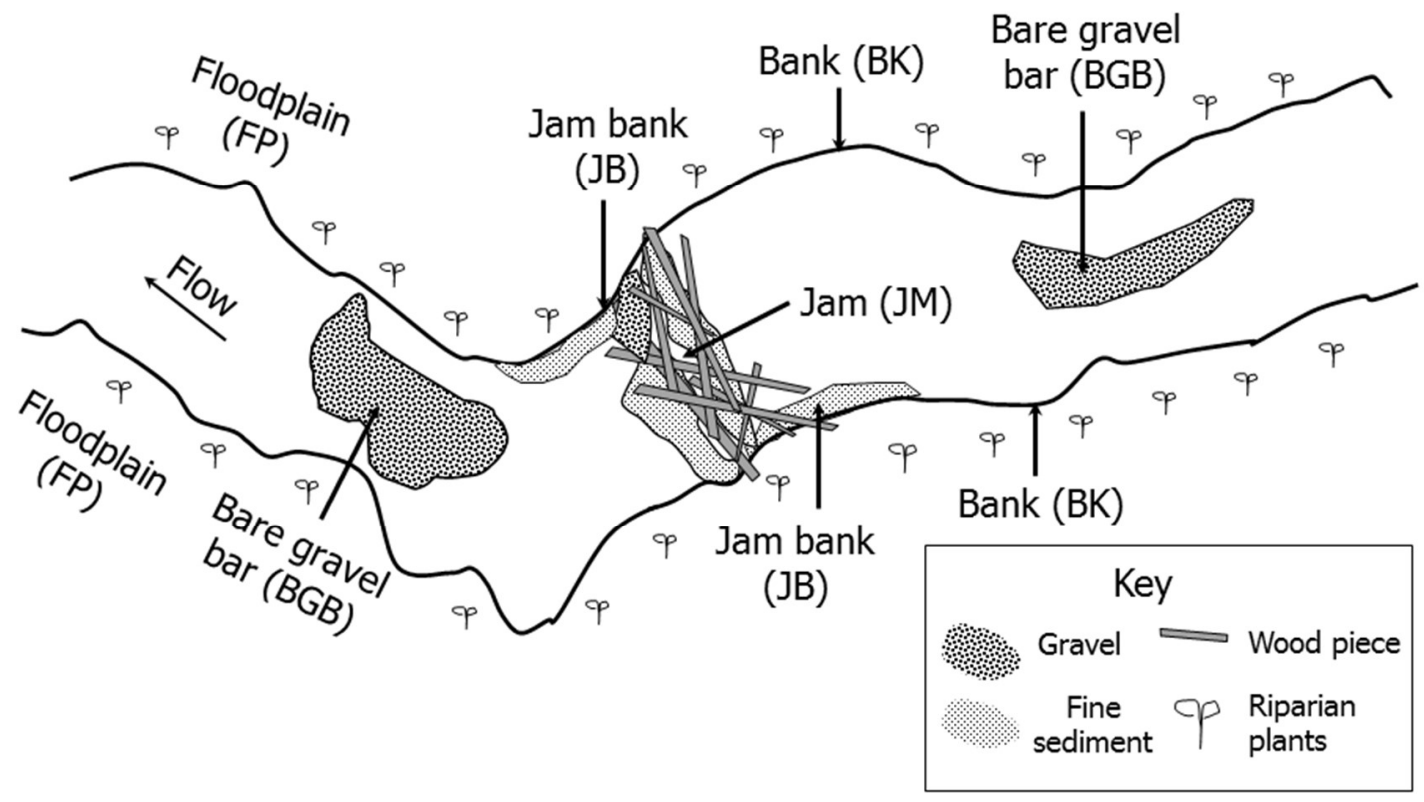

Fig. 2. Schematic representation of the typical patterning of habitat patches representative of the study reach along the Highland Water. The patches identified within the river corridor along the study reach were bare (unvegetated) gravel bar (BGB), jam (JM), jam bank (JB), bank (BK) and floodplain (FP). 

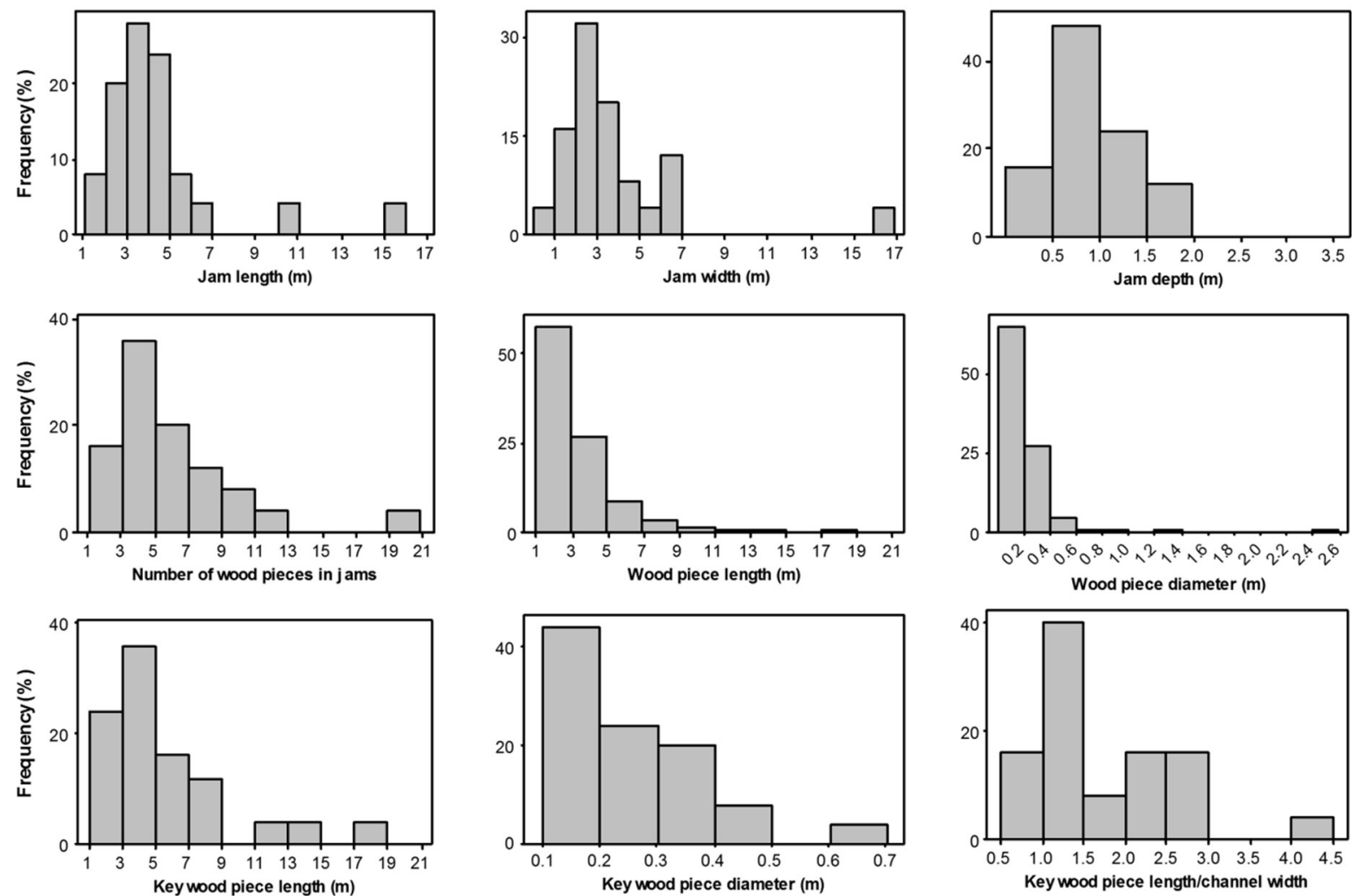

Fig. 3. Percentage frequency distributions of:

Top: wood jam length (m) (left), width (m) (middle) and, depth (m) (right)

Middle: the number (left), length (m) (middle) and diameter (m) (right) of large wood pieces found within wood jams.

Bottom: the length (m) (left), diameter (m) (middle) of key wood pieces found within large jams and the ratio of key wood piece length to channel width (right). 

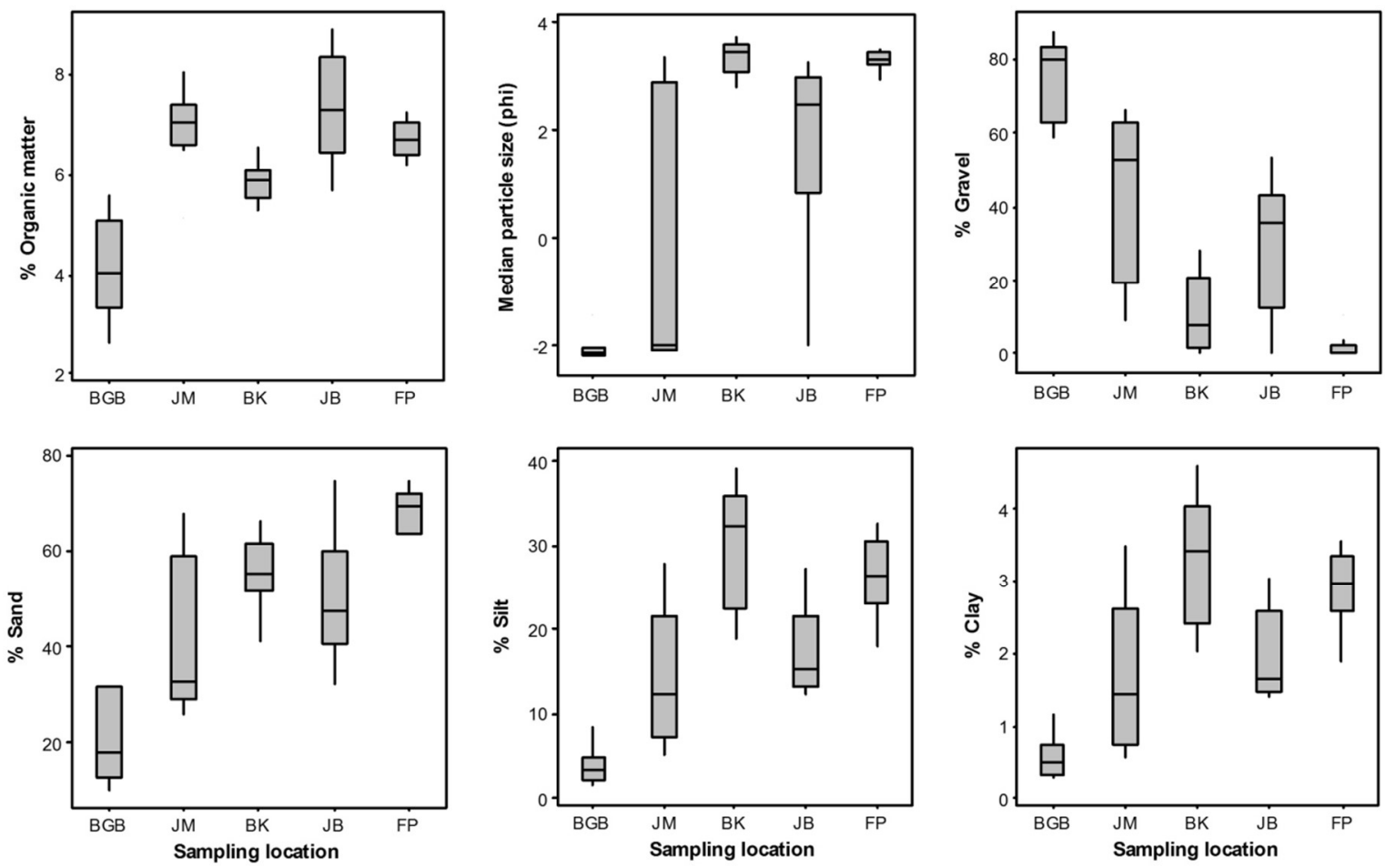

Fig. 4. Box-whisker plots illustrating sediment properties of samples from bare gravel bar (BGB), jam (JM), bank (BK), jam bank (JB) and floodplain (FP) locations. 


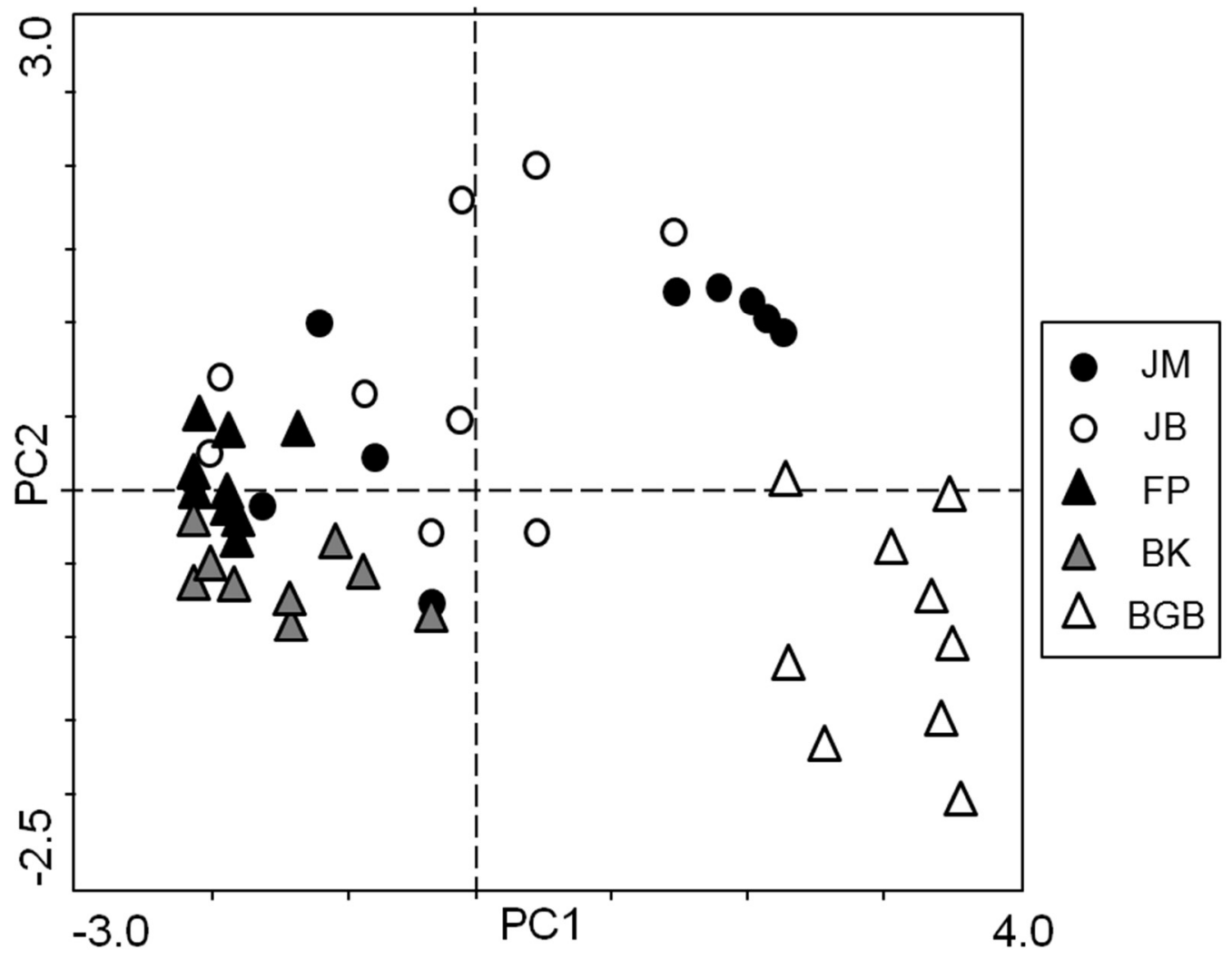

Fig. 5. Scatter plot illustrating sample scores on PC1 and PC2 of the PCA described in Table 4. Samples are coded by sampling location type (BGB, JM, BK, JB, FP). 

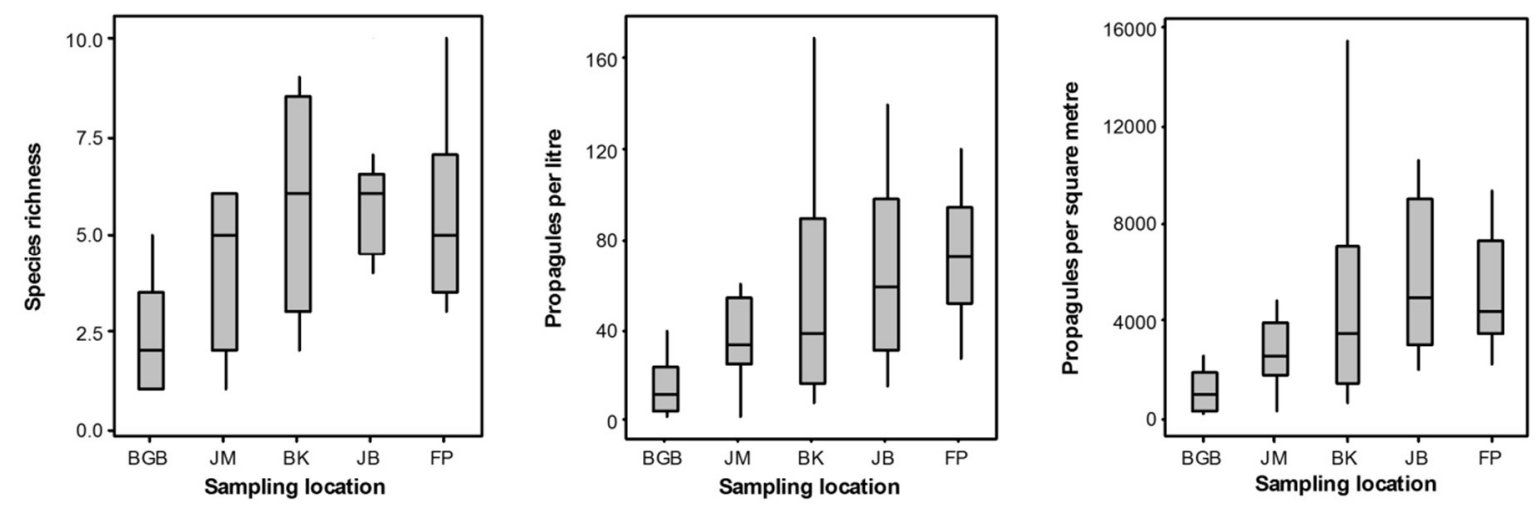

Fig. 6. Box and whisker plots illustrating propagule species richness, propagules per square metre and per litre in the five sampling location types. 

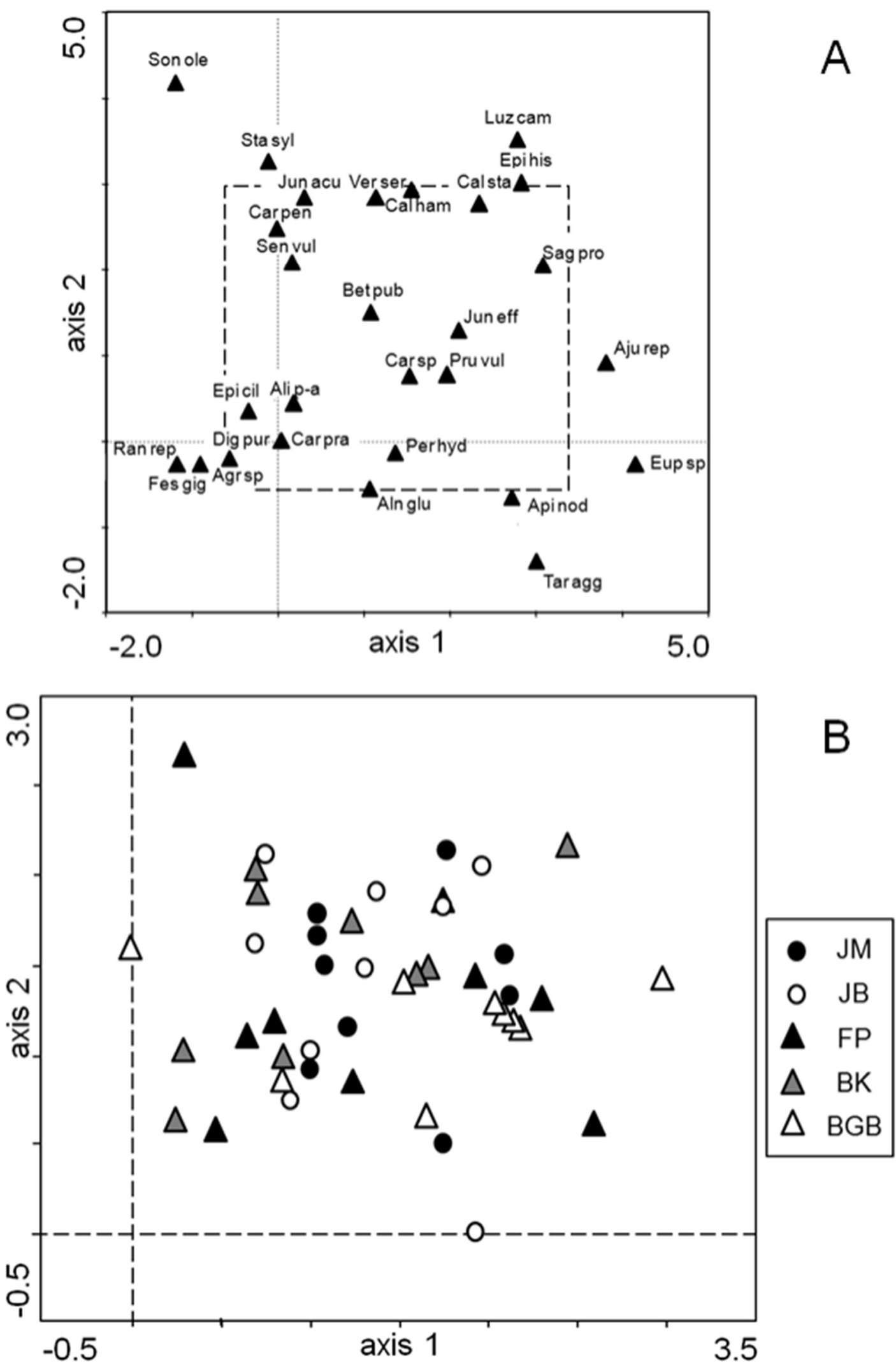

Fig. 7. DCA Ordination plot of (A) propagule species (for species names associated with abbreviations see Table 5, the dashed box marks the limits of the graph shown in (B)); (B) samples coded by sampling location type. 
